НАУКОВИЙ ВІСНИК

The

Cientific messegger of Livi National University
Veterinary Meedicine and Biotechnologies

now

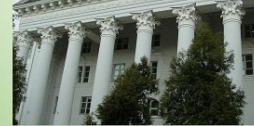

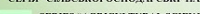

Toм 21 № 91

2019
Науковий вісник Дьвівського національного університету ветеринарної медицини та біотехнодогій імені С.3. Гжицького. Серія: Сільськогосподарські науки

Scientific Messenger of Lviv National University of Veterinary Medicine and Biotechnologies. Series: Agricultural sciences

UDC 636.4.082.25 / 575.22

\title{
Genetic structure of the Southern meat cattle breed based on microsatellite markers
}

A.S. Kramarenko

Mykolayiv National Agrarian University, Mykolayiv, Ukraine

Article info

Received 04.09.2019

Received in revised form 03.10 .2019

Accepted 04.10.2019

Mykolayiv National Agrarian

University, Georgiya

Gongadze Str., 9, Mykolayiv,

54020, Ukraine.

Tel.: +38-095-497-34-19

E-mail: kssnail1990@gmail.com
Kramarenko, A.S. (2019). Genetic structure of the Southern meat cattle breed based on microsatellite markers. Scientific Messenger of Lviv National University of Veterinary Medicine and Biotechnologies. Series: Agricultural sciences, 21(91), 21-28. doi: 10.32718/nvlvet-a9104

The Southern Meat cattle is a composite breed developed by crossing Cuban zebu (Bos indicus) with different cattle breeds (Bos taurus) - local the Red Steppe, Hereford, Charolais, Santa Gertrudis, Dairy Shorthorn. Genetic structure of the Southern meat cattle breed from the State Enterprise Experimental Farm "Askaniyske" NAAS Ukraine (Kherson region) were investigated based on the microsatellite DNA loci. Analysis included 192 animals. A panel of 12 bovine-specific microsatellite markers (TGLA227, BM2113, TGLA53, ETH10, SPS115, TGLA122, INRA23, TGLA126, BM1818, ETH3, ETH225 and BM1824), recommended of the ISAG for cattle genetic diversity studies, was selected for genetic characterization and revealing the extent of genetic diversity in the Southern Meat cattle breed. Genomic DNA was extracted from tissue samples using Nexttec column (Nexttec Biotechnology GmbH, Germany) following the manufacturer's instructions. All laboratory tests were conducted in the laboratory of Molecular Genetics, Animal Center of Biotechnology and Molecular Diagnostics, All-Russian Research Institute for Animal Husbandry named after academy member L.K. Ernst. We report the distribution and the frequency of a taurine and an indicine specific alleles in the Southern Meat cattle breed using literature data about the Zebu and different cattle breeds genetic structure based on microsatellite loci from our list. It can be assumed that the TGLA22777,

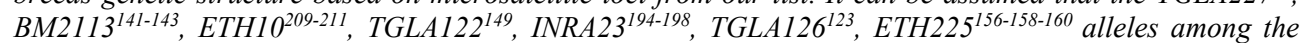
Southern Meat cattle breed examined individuals were inherited from a B. indicus ancestor. On the other

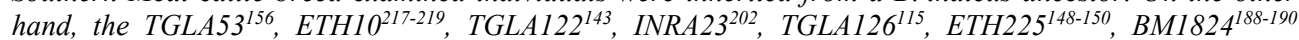
alleles in the Southern Meat cattle gene pool may be inherited from a B. taurus ancestor (i.e., taurine breeds diagnostic alleles).

Key words: Bos indicus, Bos taurus, the Southern Meat cattle breed, taurine/zebuine diagnostic alleles, microsatellite DNA loci.

\section{Генетична структура південної м'ясної породи худоби за локусами мікросателітів}

\author{
О.С. Крамаренко
}

Миколаївський національний аграрний університет, м. Миколаїв, Украӥна

Південна м'ясна порода виведена в результаті схрещування кубинського зебу (Воs indicus) з різними породами великої рогатоі худоби (Bos taurus), такими як місиева червона степова, герефорд, шароле, санта гертруда та молочний шортгорн. Генетична структура південної м'ясної породи, що утримувалася в умовах ДП ДГ “Асканійське” НААН Украйни Каховського району (Херсонська область) була досліджена з використанням локусів мікросателітів ДНК. В аналіз було включено дані щодо 192 голів. Панель, що містила 12 мікросателітних маркерів (TGLA227, BM2113, TGLA53, ETH10, SPS115, TGLA122, INRA23, TGLA126, BM1818, ETH3, ETH225 and BM1824), рекомендовані Міжнародним товариством генетики тварин (ISAG) для дослідження генетичного різноманіття худоби, було використано для генетичного аналізу генетичної мінливості тварин південної м'ясної породи. Виділення ДНК проводили на колонках Nexttec (Nexttec Biotechnologie GmbH, Germany) згідно з рекомендаиіями виробника. Всі лабораторні дослідження було проведено на базі лабораторії молекулярної генетики Центру біотехнології та молекулярної діагностики тва- 
рин Всеросійського науково-дослідного інституту твариннищтва ім. Л.К. Ернста. Нами було встановлено особливості розподілу B. taurus- та B.indicus-сnецифічних алелів серед тварин південної м'ясної породи, використовуючи літературні джерела щодо генетичної структури зебу та різних порід худоби за локусами мікросателітів ДНК з нашого списку. Зроблено припущення, щзо

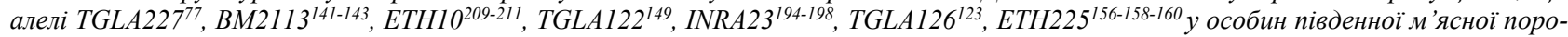

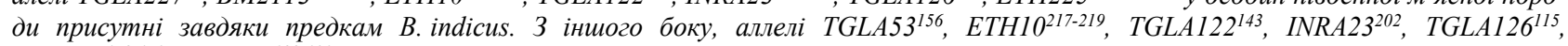
ЕTH225 $5^{148-150}$, ВМ1824 ${ }^{188-190}$ в генофонді південної м'ясної породи можуть походити від В. Таитиs предків (тобто є діагностичними алелями для порід худоби).

Ключові слова: Bos indicus, Bos taurus, південна м'ясна порода худоби, taurine/zеbиіпе діагностичні алелі, локуси мікросателіmів ДНК.

Вступ

Південна м'ясна порода (ПМП) - єдина в Європі порода м'ясної худоби, що була створена внаслідок міжвидової гібридизації між зебу (Bos indicus L., 1758) та низкою порід великої рогатої худоби (Bos taurus L., 1758). Як “батьківські” було використано такі породи, як червона степова, шортгорн, сантагертруда, герефорд та шароле (Vdovychenko et al., 2012).

На теперішній час серед тварин ПМП виділяють два підтипи - низькокровний (із “часткою” спадковості за зебу менше ніж 37,5\%) та висококровний (із часткою спадковості за зебу вище ніж 37,5\%). Вони відрізняються між собою як на підставі екстер'єру, так і за рівнем продуктивності. Крім того, за допомогою таких високополіморфних генетичних маркерів, як мікросателітів ДНК (МС-ДНК), було також доведено, що існують певні суттєві відмінності між тваринами низько- та високровного підтипів (Kramarenko, 2015a; 2015b; Kramarenko et al., 2015).

Але невирішеним залишається питання, на якому етапі перебуває процес інтеграції різних генофондів (B. indicus та B. taurus) через 50 років, що сплинули 3 початком формування цієї породи, та чи можна ідентифікувати алелі, що тварини ПМП отримали або від зебу, або від таурін.

Таким чином, головною метою даної роботи є характеристика генетичної структури тварин ПМП (насамперед характеру розподілу алельних частот локусів МС-ДНК) та визначення генетичних маркерів, що можуть бути використані для taurus/indicusдиференціації.

\section{Матеріал і методи досліджень}

Дослідження було проведено на поголів'ї корів ПМП (всього 192 голови) ДП ДГ “Асканійське” НААН України Каховського району Херсонської області.
Матеріалом для дослідження були біологічні проби тканини (вушні вищипи).

У дослідженні використовували 12 мікросателітних локусів, що рекомендовані ISAG: TGLA227, BM2113, TGLA53, ETH10, SPS115, TGLA122, INRA23, TGLA126, BM1818, ETH3, ETH225 та BM1824.

Всі лабораторні дослідження було проведено в умовах лабораторії молекулярної генетики тварин Центру біотехнології та молекулярної діагностики тварин Всеросійського науково-дослідного інституту (ВНДІ) тваринництва ім. Л.К. Ернста.

Виділення ДНК проводили на колонках Nexttec (Nexttec Biotechnologie GmbH, Germany) згідно 3 рекомендаціями виробника та перхлоратним методом за методиками ВНДІ тваринництва ім. Л.К. Ернста. Аналіз ДНК і постановку ПЛР проводили згідно з методичними розробками Центру біотехнології та молекулярної діагностики тварин ВНДІ тваринництва ім. Л.К. Ернста (Zinovieva et al., 1998).

Аналіз ампліфікованих фрагментів здійснювали за допомогою приладу для капілярного електрофорезу ABI 3130xl (Applied Biosystems, США). Для ідентифікації алелів мікросателітних локусів використовували програму GeneMapper ID v. 3.2. Обробку даних капілярного електрофорезу проводили шляхом переведення довжин фрагментів у числовий вираз шляхом порівняння їх рухливості зі стандартом молекулярної маси ДНК.

Для всіх тварин, що було включено до аналізу, розраховано частоти генотипів та алелів за кожним локусом мікросателітів (Weir, 1996). Розрахунки здійснено за допомогою комп'ютерної програми GenAIEx v. 6.5 (Peakall \& Smouse, 2012).

\section{Результати та їх обговорення}

На рисунках 1 та 2 наведено розподіл алельних частот за 12 локусами мікросателітів ДНК (МС-ДНК), використаних нами для аналізу генетичного поліморфізму тварин ПМП.

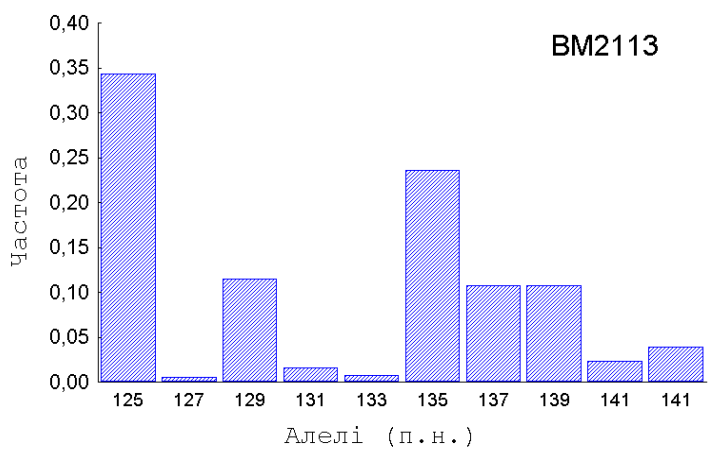



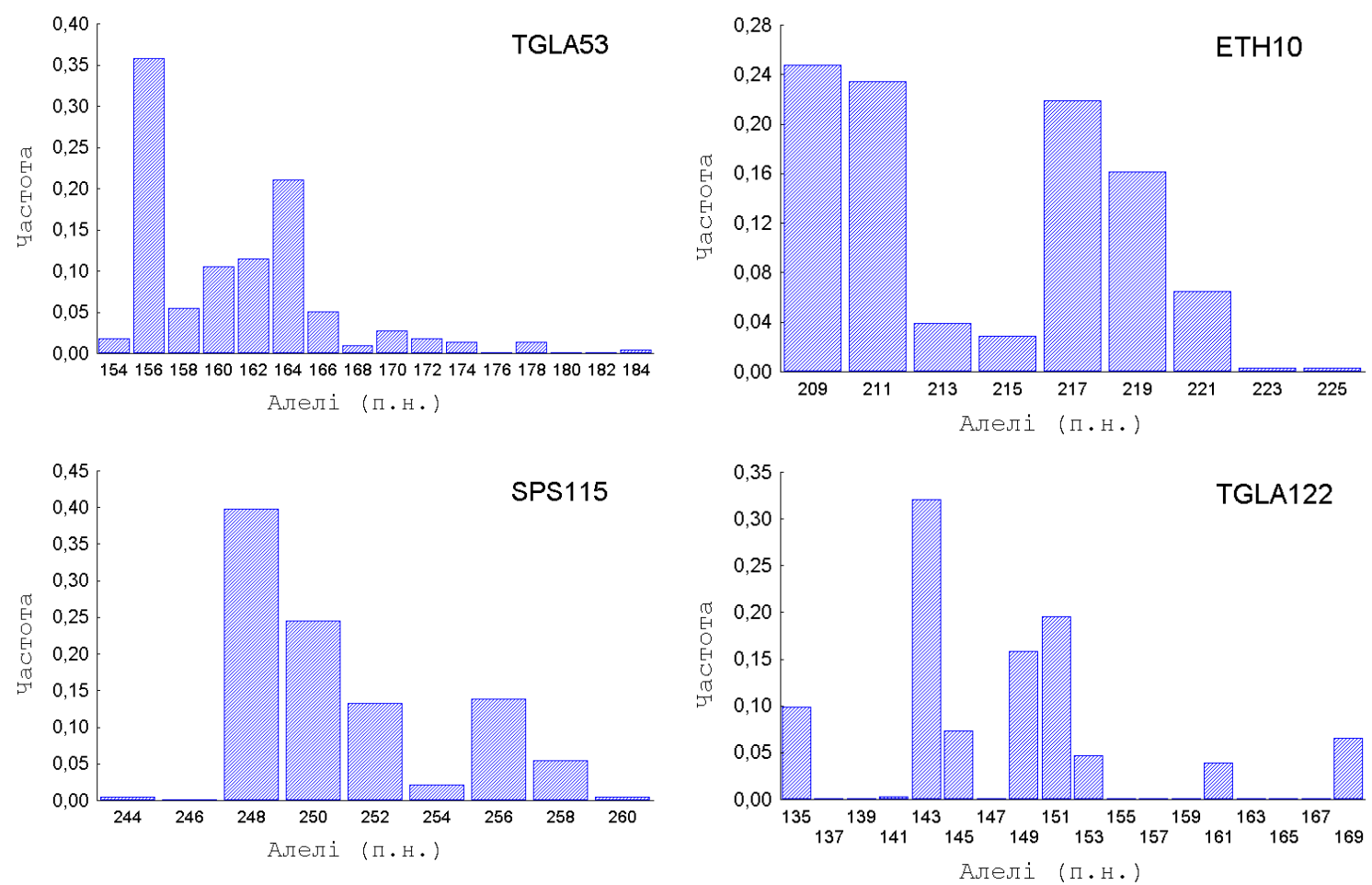

Рис. 1. Розподіл алельних частот за локусами МС-ДНК TGLA227, BM2113, TGLA53, ETH10, SPS115 та TGLA122 тварин ПМП

Найбільш характерною особливістю, що була встановлена при аналізі отриманих розподілів для більшості локусів МС-ДНК, $є$ їх бімодальний характер. Можливим поясненням отриманих даних може бути те, що ПМП створювалася в результаті схрещу- вання не лише порід худоби різного напряму продуктивності (молочного - червона степова порода, м'ясного - шароле, герефорд, санта-гертуда та шортгорн), а й $з$ додаванням генетичного матеріалу, що належить до B. indicus (Vdovychenko et al., 2012).
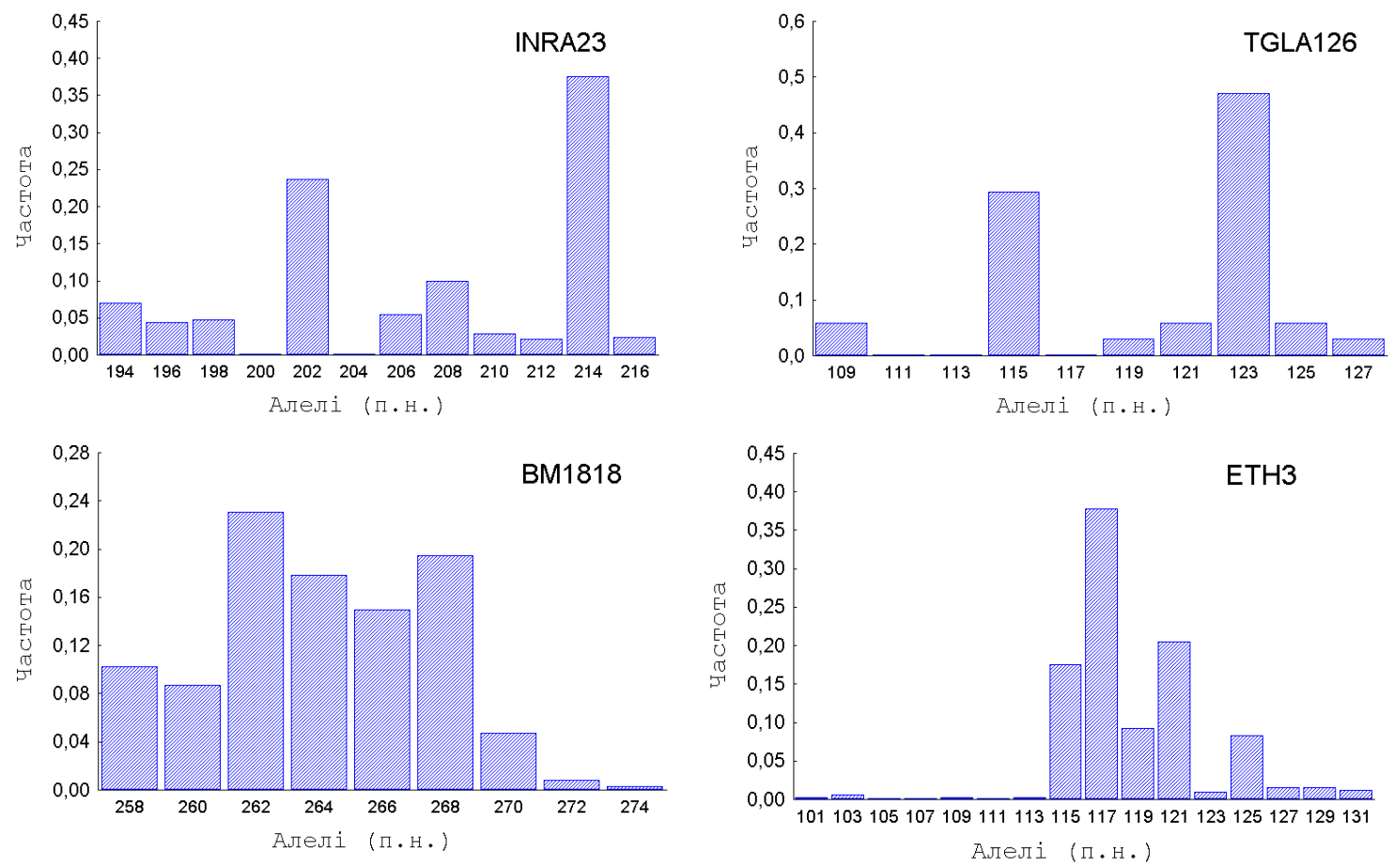

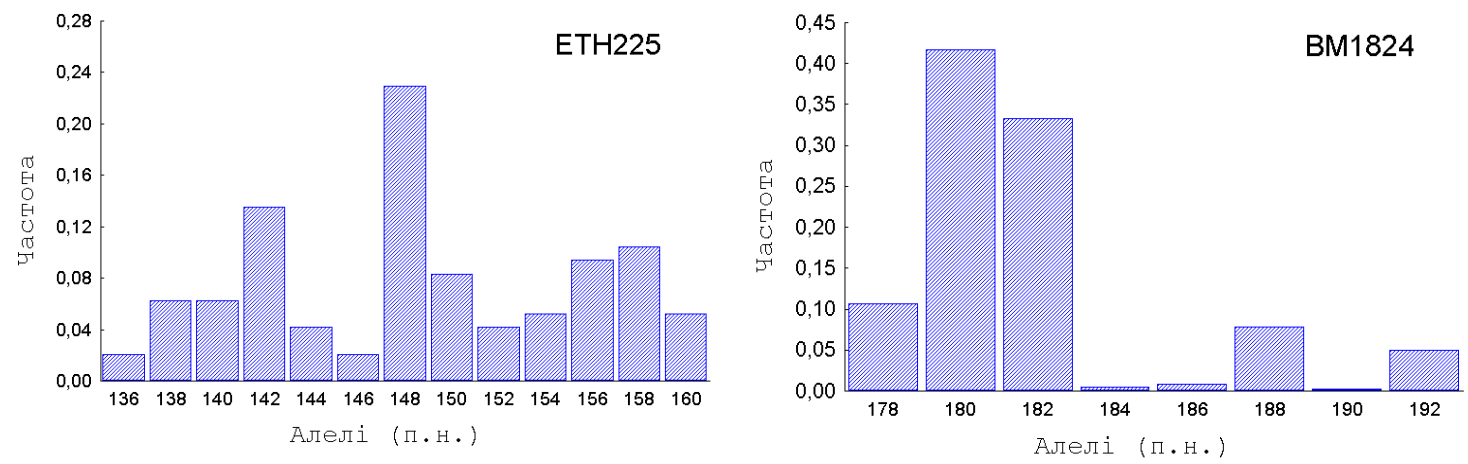

Рис. 2. Розподіл алельних частот за локусами МС-ДНК INRA23, TGLA126, BM1818, ETH3, ETH225 та BMI824 тварин ПМП

Тому для детальнішого аналізу механізмів формування генетичного різноманіття у тварин ПМП були зібрані та опрацьовані літературні дані щодо найбільш поширених (з частотою $>0,2$ ) алелів у тварин як різних порід ВРX, так і різних популяцій зебу (табл. 1-4). Крім комерційних м'ясних порід, нами також до аналізу було включено дані для деяких автохтонних порід, генофонд яких міг збіднити.
Локус TGLA227. У тварин ПМП можна виділити чотири алеля (чи інтервалу алелів), які мають підвищені частоти - TGLA22777, TGLA22 $7^{81-83}, T G L A 227^{89}$ та $T G L A 227^{97}$ (рис. 1). Перший 3 них (TGLA22777) траплявся лише серед зебу i, таким чином, його можна розглядати як indicus-специфічний (табл. 1). Решта алелів виявляли у різних порід ВРХ (табл. 2-4), причому як комерційних, так і автохтонних. Відповідно ïx можна розглядати як taurus-специфічні алелі.

Таблиця 1

Найбільш поширені алелі МС-ДНК у популяціях зебу та тварин ПМП, п. н.

\begin{tabular}{|c|c|c|c|c|c|c|}
\hline \multirow{2}{*}{ Локус } & \multicolumn{5}{|c|}{ Популяція (літературні дані ${ }^{1}$ ) } & \multirow{2}{*}{$\begin{array}{c}\text { Власні } \\
\text { дані }^{2}\end{array}$} \\
\hline & Zebu-1 & Zebu-2 & Zebu-3 & Zebu-4 & Zebu-5 & \\
\hline TGLA227 & 79 & 77 & 77 & 77 & 77 & $\mathbf{7 7}, 89$ \\
\hline BM2113 & 131,143 & $129,135,141$ & 123,131 & 141 & $129,139,141$ & 125,135 \\
\hline TGLA53 & 159 & $\mathrm{na}^{3}$ & 158 & 160 & 160,168 & 156,164 \\
\hline ETH10 & 210,212 & 209,213 & 209 & 209,213 & $209,211,213$ & $\mathbf{2 0 9}, \mathbf{2 1 1}, 217,219$ \\
\hline SPS115 & 247 & 248 & $239,241,243$ & $246,248,250$ & 246,248 & $\mathbf{2 4 8}, 250$ \\
\hline TGLA126 & 124 & 123 & 123,125 & 123,125 & 123,125 & $115, \mathbf{1 2 3}$ \\
\hline TGLA122 & 137,149 & 153 & 141,143 & $145,149,151$ & $137,151,153$ & $143,149,151$ \\
\hline INRA23 & 215 & 214 & 208 & 214 & 214 & 202,214 \\
\hline BM1818 & na & na & na & na & na & $262-268$ \\
\hline ЕTH3 & 113 & na & 111 & 115,117 & 115,117 & $\mathbf{1 1 5}, \mathbf{1 1 7}, 121$ \\
\hline ETH225 & 158 & 158 & 136,144 & 160 & 160 & 148 \\
\hline BM1824 & 183 & 180,182 & 180 & 180,182 & 180,182 & 180,182 \\
\hline
\end{tabular}

Примітки: ${ }^{1}$ Zebu-1 - Kesvulu et al., 2009; Zebu-2 - Bicalho et al., 2006; Zebu-3 - Escobar et al., 2009; Zebu-4 - Novoa \& Usaquen, 2010; Zebu-5 - Gomez et al., 2013. ${ }^{2}$ Напівжирним шрифтом позначені алелі, що трапляються як у літературних джерелах, так і у власних результатах. ${ }^{3}$ na - дані відсутні (тут і далі)

Локус ВМ2113. Найбільшу частоту мали алель $B M 2113^{125}$ та інтервал алелів BM2113 $135-137-139$ (рис. 1). Однозначного висновку щодо джерела походження цих алелів серед тварин ПМП на підставі аналізу їх поширення у худоби різних порід (та видів) дійти неможливо. Підвищену частоту алеля $B M 2113^{125}$ було зареєстровано лише у ісландської худоби (Asbjarnardottir et al., 2010) та словенської худоби Cika (Simčić, et al., 2008).

Алелі ВM2113 135-137-139 були більш поширені серед зебу (Bicalho et al., 2006), а також худоби порід шароле (Kundrat \& Urban, 2007), герефорд (Janik et al.,
2002; Kundrat \& Urban, 2007), червоної степової (Kramarenko et al., 2018), а також автохтонних порід Rhodope Shorthorn (Teneva et al., 2007) та Cika (Simčić et al., 2008).

Такий характер поширення цих алелів локусу ВM2113 свідчить про те, що за їх допомогою неможливо однозначного провести диференціювання між видами роду Bos та навіть окремими породами таурін. 3 іншого боку, для зебу було характерно підвищення частоти “найдовших" алелів - BM2113 141-143 (табл. 1). Таким чином, можна розглядати ці алелі як indicusспецифічні. 
Таблиця 2

Найбільш поширені алелі МС-ДНК у популяціях худоби породи шароле та тварин ПМП, п. н.

\begin{tabular}{|c|c|c|c|c|c|c|}
\hline \multirow{2}{*}{ Локус } & \multicolumn{5}{|c|}{ Популяція (літературні даніі) } & \multirow{2}{*}{$\begin{array}{c}\text { Власні } \\
\text { дані }^{2}\end{array}$} \\
\hline & Char-1 & Char-2 & Char-31 & Char-32 & Char-33 & \\
\hline TGLA227 & 89 & $83,89,91$ & na & na & na & 77,89 \\
\hline BM2113 & 131 & 131,135 & 131 & 131 & 133 & $125, \mathbf{1 3 5}$ \\
\hline TGLA53 & na & na & $151,153,157$ & 157 & 157 & $\mathbf{1 5 6}, 164$ \\
\hline ETH10 & 217 & 217 & 215 & 209,211 & 211 & $\mathbf{2 0 9}, \mathbf{2 1 1}, \mathbf{2 1 7}, 219$ \\
\hline SPS115 & 248 & 248 & na & na & na & $\mathbf{2 4 8}, 250$ \\
\hline TGLA126 & 115 & 115 & na & na & na & $\mathbf{1 1 5}, 123$ \\
\hline TGLA122 & 151 & 143,151 & na & na & na & $143,149, \mathbf{1 5 1}$ \\
\hline INRA23 & 206 & 202,206 & $203,207,207$ & $205,207,209$ & 199, 203 & $\mathbf{2 0 2}, 214$ \\
\hline BM1818 & 262 & na & na & na & na & 262-268 \\
\hline ЕTH3 & 117 & 117,125 & na & na & na & $115, \mathbf{1 1 7}, 121$ \\
\hline ETH225 & 148 & 148,150 & na & na & na & 148 \\
\hline BM1824 & 182 & $180,182,188$ & 178,182 & 178,180 & $180,182,184$ & 180,182 \\
\hline
\end{tabular}

Примітки: ${ }^{1}$ Char-1 - Putnova et al., 2011; Char-2 - Kundrat \& Urban, 2007; Char-31, Char-32, Char-33 - Sifuentes-Rincon et al., 2007 (три популяції). ${ }^{2}$ Напівжирним шрифтом позначені алелі, що зустрічається як у літературних джерелах, так і у власних результатах

Локус TGLA53. У розподілі частот алелів за даним локусом було два піки - для алеля TGLA53 $3^{156}$ та інтервалу алелів TGLA53 ${ }^{162-164-166}$ (рис. 1). Причому, перший мав дуже високу частоту в особин трьох популяцій породи шароле (Sifuentes-Rincón et al., 2007).
Таким чином, можна припустити, що цей алель $є$ специфічним для худоби цієї породи.

Інші алелі бувають серед тварин порід герефорд (Janik et al., 2002), симентал (Stevanović et al., 2009), червона степова (Kramarenko et al., 2018) та сицилійської худоби (Cosenza et al., 2015).

Таблиця 3

Найбільш поширені алелі МС-ДНК у популяціях худоби герефордської, симентальської порід та тварин ПМП, П. н.

\begin{tabular}{|c|c|c|c|c|c|c|}
\hline \multirow{2}{*}{ Локус } & \multicolumn{5}{|c|}{ Популяція (літературні дані1) } & \multirow{2}{*}{$\begin{array}{c}\text { Власні } \\
\text { дані }^{2}\end{array}$} \\
\hline & Heref-1 & Heref-2 & Heref-3 & Simm-1 & Simm-2 & \\
\hline TGLA227 & $91,93,95$ & 89,91 & 94 & 80 & 81 & 77,89 \\
\hline BM2113 & 133,139 & 135,139 & na & 128 & 131 & 125,135 \\
\hline TGLA53 & 160,162 & na & na & 164 & na & $156, \mathbf{1 6 4}$ \\
\hline ETH10 & $219,221,223$ & 217,219 & $218,220,222$ & 214 & 217 & 209, 211, 217, 219 \\
\hline SPS115 & 248 & 248,260 & na & 242 & 248 & $\mathbf{2 4 8}, 250$ \\
\hline TGLA126 & 117 & 115,117 & 115,117 & 114,116 & 115 & $\mathbf{1 1 5}, 123$ \\
\hline TGLA122 & 143,153 & 143 & na & 150 & 151 & $\mathbf{1 4 3}, 149, \mathbf{1 5 1}$ \\
\hline INRA23 & 206,216 & 214 & na & $208,212,214$ & 214 & 202,214 \\
\hline$B M 1818$ & na & na & na & na & 268 & $262-268$ \\
\hline ЕTH3 & 117,119 & 117,119 & na & $112,114,124$ & 117 & $115, \mathbf{1 1 7}, 121$ \\
\hline ETH225 & 146,148 & 148,150 & na & 144 & 150 & 148 \\
\hline BM1824 & $180,182,184$ & 182 & na & 182,188 & 188 & $180, \mathbf{1 8 2}$ \\
\hline
\end{tabular}

Примітки: ${ }^{1}$ Heref-1 - Janik et al., 2002; Heref-2 - Kundrat \& Urban, 2007; Heref-3 - Yoon et al., 2005; Simm-1 - Stevanović et al., 2009; Simm-2 - Putnova et al., 2011. ${ }^{2}$ Напівжирним шрифтом позначені алелі, що зустрічаються як у літературних джерелах, так і у власних результатах

Локус ЕTH10. Розподіл частот алелів за цим локусом має чітко виражену U-подібну форму із двома піками, що припадають на алелі ETH10 209-211 та $E T H 10^{217-219}$ (рис. 1). Порівняння наших результатів із літературними даними вказує на те, що перша група алелів притаманна зебу (табл. 1), тимчасом як друга зустрічається в усіх досліджених породах ВРX (табл. 2-4).

Таким чином, алелі $E T H 10^{209-211}$ можна розглядати як зебу-специфічні, тимчасом як $E T H 10^{217-219}$ - як спільні для усіх таурін.
Локус SPS115. Нами було встановлено чіткий одно-модальний тип розподілу частот алелів даного локусу із піком, що припадає на алелі з довжиною у 248-250 п. н. (рис. 1). Як свідчать результати аналізу літературних джерел, практично всі досліджені популяції зебу та ВРX мали підвищену частоту саме за цими алелями (табл. 1-4). Таким чином, їх варто розглядати як специфічні для роду Bos. 
Таблищя 4

Найбільш поширені алелі МС-ДНК в популяціях худоби червоної степової породи, локальних порід Свропи та тварин ПМП, П. н.

\begin{tabular}{|c|c|c|c|c|c|c|}
\hline \multirow[b]{2}{*}{ Локус } & \multicolumn{5}{|c|}{ Популяція (літературні дані1) } & \multirow{2}{*}{$\begin{array}{c}\text { Власні } \\
\text { дані }^{2}\end{array}$} \\
\hline & Red Steppe & Sicilian cattle & $\begin{array}{c}\text { Icelandic } \\
\text { cattle }\end{array}$ & $\begin{array}{l}\text { Rhodope } \\
\text { Shorthorn }\end{array}$ & Cika cattle & \\
\hline TGLA227 & $81,83,89,91$ & 82,90 & 89,97 & $84,88,96$ & 82 & $77, \mathbf{8 9}$ \\
\hline$B M 2113$ & 135,137 & $128,130,132$ & 125 & 135 & $124,128,134$ & $125, \mathbf{1 3 5}$ \\
\hline TGLA53 & 166 & 159,167 & 176 & 160 & na & 156,164 \\
\hline ETH10 & 217,219 & 214,216 & 219 & 218 & $215,217,221$ & $209,211,217,219$ \\
\hline SPS115 & 248 & 243 & 248 & 248 & 244 & 248,250 \\
\hline TGLA126 & 115 & 116 & 115,117 & 119 & 116,118 & $\mathbf{1 1 5}, 123$ \\
\hline$T G L A 122$ & 141,143 & 142,152 & $143,147,149$ & 142,144 & 151 & $\mathbf{1 4 3}, 149,151$ \\
\hline INRA23 & 212 & $205,207,213$ & 214 & 207,215 & 212 & 202,214 \\
\hline BM1818 & 262,266 & na & na & na & na & 262-268 \\
\hline ЕTH3 & 117,119 & 114,122 & $119,125,127$ & 117,125 & na & $115, \mathbf{1 1 7}, 121$ \\
\hline ETH225 & 140,156 & 144,146 & 140,148 & $140,144,148$ & 144,146 & 148 \\
\hline BM1824 & 182,188 & $182,184,190$ & 180,188 & $182,184,190$ & 183,189 & 180,182 \\
\hline
\end{tabular}

Rhodope Shorthorn - Teneva et al., 2007; Cika cattle - Simčić et al., 2008. ${ }^{2}$ Напівжирним шрифтом позначені алелі, що зустрічаються як у літературних джерелах, так і у власних результатах

Локус TGLA122. За частотою алелів цього локусу встановлено два чітких піки. Перший відповідає алелю TGLA122143, а другий - інтервалу алелів TGLA122 $2^{149-151}$ (рис. 1).

Порівняння із доступними літературними даними свідчить про те, що алель TGLA122 143 виявляли із високою частотою у зебу лише в одному випадку (Escobar et al., 2009). Водночас у тварин різних порід ВРX його висока частота фіксувалася досить часто (табл. 2-4). Алелі TGLA122 $2^{149-151}$ були зафіксовані як у представників виду $B$. indicus, так і в різних таурін. Можна припустити, що перший 3 них характерніший для різних порід ВРХ, тимчасом як другий - більш притаманний для зебу.

Локус INRA23. Характер розподілу за частотою алелів за цим локусом у досліджених тварин ПМП також має чітко виражений бімодальний тип (рис. 2). Перший пік припадає на алель довжиною 202 п. н., а другий - на алель INRA23214.

Із усіх проаналізованих нами популяцій, алель $I N R A 23^{202}$ був широко розповсюджений лише у худоби породи шароле (Kundrat \& Urban, 2007; SifuentesRincon et al., 2007). 3 іншого боку, алель INRA23214, навпаки, досить часто виявляли як у популяціях ВРХ, так і зебу (табл. $1,3,4)$. Таким чином, як і у випадку із локусом TGLA53, можна припустити, що алель $I N R A 23^{202} \epsilon$ специфічним для худоби породи шароле.

Локус TGLA126. Для цього локусу для досліджених тварин ПМП зареєстровано два піки. Перший відповідає алелю $T G L A 126^{115}$, а другий - алелю TGLA126 $6^{123}$ (рис. 2).

Порівняння цих результатів із літературними даними свідчить про те, що перший алель притаманний лише ВРХ (табл. 2-4), а другий - лише зебу (табл. 1). Тож однозначно можна стверджувати, що алель $T G L A 126^{115}$ є taurus-специфічним, тимчасом як алель TGLA126 $6^{123}$ - indicus-специфічним.

Локус ВМ1818 характеризується відносно рівномірним розподілом за частотою алелів із розмірами 262-268 п. н. (рис. 2). Крім того, відсутність літерату- рних даних щодо цього локусу унеможливлює порівняльний аналіз. Лише можна зазначити, що алелі BM1818 262-268 3 високою частотою виявляли у різних порід ВРX - шароле, симентальська (Putnova et al., 2011) та червона степова (Kramarenko et al., 2018).

Локус $\boldsymbol{E T H 3}$ також характеризується одномодальним типом розподілу за частотами алелів у тварин дослідженої популяції ПМП (рис. 2). Крім того, аналіз літературних даних свідчить про те, що найбільш поширені у тварин ПМП алелі (довжиною 115-121 п. н.) є також широко притаманні як тваринам різних порід ВРХ (табл. 2-4), так і зебу (табл. 1). Таким чином, алелі локусу ETH3 не можуть бути використані для indicus/taurus-диференціації.

Локус ETH225. Для цього локусу у тварин дослідженої популяції ПМП можна виділити три піки; перший припадає на алелі ETH225 $5^{140-142}$, другий - на алель $E T H 225^{148}$, третій - на інтервал алелів ETH225 $5^{156-158}$ (рис. 2).

Порівняння із літературним даними свідчить про те, що найбільш “довгі” алелі зустрічалися лише у зебу (табл. 1), тимчасом як алелі із довжиною в 148150 п. н. мали підвищену частоту у тварин різних порід ВРХ (табл. 2-4).

Таким чином, алелі ETH225 $5^{156-158-160}$ можна розглядати як зебу-специфічні, тимчасом як ETH225 $5^{148-150}$ як специфічні для таурін.

Локус ВМ1824. Тип розподілу частот алелей цього локусу у тварин ПМП мав одномодальний, але асиметричний характер. Найбільш поширеними в популяції ПМП були алелі $B M 1824^{180}$ та $B M 1824^{182}$. Водночас із відносно низькою частотою зустрічалися декілька найбільш “довгих” алелів (рис. 2).

Аналіз літературних даних свідчить про те, що алелі $B M 1824^{180}$ та BM1824 $4^{182}$ поширені як в популяціях зебу, так і різних порід ВРХ (рис. 1-4). Таким чином, ці алелі також не можуть бути використані як діагностичні для indicus/taurus-диференціації.

Водночас характерною особливістю для різних популяцій великої рогатої худоби є висока частота 
найбільш “довгих” алелів (BM1824 $\left.{ }^{188-190}\right)$. Можливо, ці алелі є більш специфічними для ВРХ.

Таким чином, характер розподілу алелів 12 мікросателітних локусів ДНК, який нами було використано для аналізу тварин ПМП, може бути пояснений процесами інтеграції генофонду як зебу, так і різних порід ВРХ. Незважаючи на майже 50-річний генезис цієї породи, їі алелофонд характеризується підвищеними частотами алелів, притаманних як зебу, так і B. taurus (табл. 5).

Раніше алелі BM2113 ${ }^{142}$ та ETH10 209-211 вже характеризувалися як специфічні для зебу, а алелі
$B M 1824^{189}$ та $E T H 10^{219}$ - як специфічні для таурін (Ibeagha-Awemu et al., 2004). 3 іншого боку, Х.П. Лірон зі спіавторами (Lirón et al., 2006) також розглядали алелі ETH2225 157-159 як діагностичні для inducis/taurus-диференціації. В роботі Р.Т. Лофтус 3 співавторами (Loftus et al., 1999) вказано на значну інтрогресію генів зебу серед порід Близького Сходу, а алелі $E T H 10^{207-209-211}$ та ETH225 $5^{153-159}$ використовувалися цими авторами для оцінки ступеня цієї інтрогреciï.

\section{Таблиця 5}

Алелі мікросателітних локусів, що можуть розглядатися як специфічні для зебу та ВРХ

\begin{tabular}{|c|c|}
\hline indicus-специфічні алелі & taurus-специфічні алелі \\
\hline TGLA22777, & TGLA53156 (лише для породи шароле), \\
\hline$B M 2113^{141-143}$, & $\overline{E T H 10^{217-2}} 19$ \\
\hline ETH10 209-211 & TGLA122 $2^{143}$ \\
\hline TGLA122 $2^{149}$ & $I N R A 23^{202}$ (лише для породи шароле), \\
\hline INRA23 $3^{194-198}, T G L A 126^{123}$, & $\overline{T G L A 126^{115}}$ \\
\hline ETH225 $5^{156-158-160}$ & $\underline{E T H} 225^{148-150}$, \\
\hline & $B M 1824^{188-190}$ \\
\hline
\end{tabular}

Примітка: підкреслено алелі (чи інтервали алелів), специфічність яких ще потребує підтвердження

\section{Висновки}

1. Особливості алельного розподілу за використаними локусами МС-ДНК серед тварин ПМП тісно пов'язані з процесами інтеграції генофонду зебу i вихідних порід ВРХ. На теперішній момент генезису ПМП, іiі алелофонд характеризується підвищеними частотами алелів, притаманних як зебу (TGLA22777, BM2113 $3^{141-143}$, ETH10 $0^{209-211}$, TGLA122 $2^{149}$, INRA23 $3^{194-198}$, $\left.T G L A 126^{123}, E T H 225^{156-158-160}\right)$, так і BPX (TGLA53 ${ }^{156}$, ETH10 ${ }^{217-219}, \quad T G L A 122^{143}$, INRA23 $3^{202}$, TGLA126 $6^{115}$, ETH225 $5^{148-150}$, BM1824 $4^{188-190}$ ).

2. Встановлені ідентифікаційні taurus/indicus-алелі для тварин ПМП та його вихідних порід можуть бути використані у практичній селекції з подальшого удосконалення та підвищення консолідації новоствореної вітчизняної породи зі збереженням оптимального рівня ії генетичної гетерогенності.

Перспективи подальших досліджень можуть бути спрямовані на пошук можливих асоціацій між локусами МС-ДНК та продуктивними ознаками тварин ПМП, наприклад ростовими ознаками, що характеризують їі м'ясну продуктивність.

Подяки. Публікація містить результати досліджень, проведених за грантом Президента України для підтримки наукових досліджень молодих учених (Ф82/2019).

\section{References}

Asbjarnardottir, M.G., Kristjansson, T., Jonsson, M.B., \& Hallsson, J.H. (2010). Analysis of genetic diversity and population structure within the Icelandic cattle breed using molecular markers. Acta Agriculturae Scand Section A, 60(4), 203-210. doi: 10.1080/09064702.2010.538714.
Bicalho, H.M.S., Pimenta, C.G., Mendes, I.K.P., Pena, H.B., Queiroz, E.M., \& Pena, S.D.J. (2006). Determination of ancestral proportions in synthetic bovine breeds using commonly employed microsatellite markers. Genetics and Molecular Research, 5(3), 432437. PMID: 17117357.

Cosenza, M., Reale, S., Lupo, T., Vitale, F., \& Caracappa, S. (2015). Allele frequencies of microsatellite loci for genetic characterization of a Sicilian bovine population. Genetics and Molecular Research, 14(1), 691699. doi: 10.4238/2015.January.30.12.

Escobar, C.H., Ángel, M.O., Alfonso, H.O., \& Guerra, M.T. (2009). Genetic variability of the zebu cattle breed (Bos indicus) in the departament of Huila, Colombia using microsatellite molecular markers. Acta Biológica Colombiana, 14(3), 173-180. http://www.scielo.org.co/scielo.php?script=sci_arttext \&pid=S0120-548X2009000300013.

Gómez, Y.M., Fernández, M., Rivera, D., Gómez, G., \& Bernal, J.E. (2013). Genetic characterization of colombian Brahman cattle using microsatellites markers. Russian Journal of Genetics, 49(7), 737-745. doi: 10.1134/S1022795413070041.

Ibeagha-Awemu, E. M., Jann, O. C., Weimann, C., \& Erhardt, G. (2004). Genetic diversity, introgression and relationships among West/Central African cattle breeds. Genetics Selection Evolution, 36(6), 673-690. doi: 10.1051/gse:2004024.

Janik, A., Zabek, T., \& Radko, A. (2002). Identyfikacja polimorfizmu 11 loci mikrosatelitow u bydla rasy hereford. Medycyna Weterynaryjna, 58(11), 867-870. http://www.medycynawet.edu.pl/images/stories/pdf/di gital/2002/200211867871.pdf (in Polish).

Kesvulu, P.C., Rao, G.N., Niyazahmed, A.S., \& Gupta, B.R. (2009). Molecular genetic characterization of Punganur cattle. Tamilnadu Journal of Veterinary and 
Animal Sciences, 5(5), 179-185. https://pdfs.semanticscholar.org/2e53/0ae8d8c2f74402 2dd5cb0e71db428a0c2a30.pdf.

Kramarenko, A.S., Gladyr, E.A., Kramarenko, S.S., Pidpala, T.V., Strikha, L.A., \& Zinovieva, N.A. (2018). Genetic diversity and bottleneck analysis of the Red Steppe cattle based on microsatellite markers. Ukrainian Journal of Ecology, 8(2), 12-17. doi: $10.15421 / 2018303$.

Kramarenko, O.S. (2015a). Analiz henetychnoyi dyferentsiatsiyi za lokusamy mikrosatelitiv khudoby pivdennoyi m'yasnoyi porody. Zbirnyk naukovykh prats' "Tekhnolohiya vyrobnytstva i pererobky produktsiyi tvarynnytstva", 1(116), 31-35 (in Ukrainian).

Kramarenko, O.S. (2015b). Analiz henetykodemohrafichnykh protsesiv $\mathrm{v}$ populyatsiyi khudoby pivdennoyi m'yasnoyi porody. Visnyk ahrarnoyi nauky Prychornomor'ya, 1(82), 203-209 (in Ukrainian).

Kramarenko, O., Gladyr, O., Zinov'eva, N., Naydyonova, V., Dubinskiy, O., \& Gill, M. (2015). Analiz henetychnoho polimorfizmu za lokusamy mikrosatelitiv khudoby pivdennoyi m'yasnoyi porody. Zbirnyk naukovykh prats' Podil's'koho derzhavnoho ahrarnotekhnichnoho universytetu 23, 382-390 (in Ukrainian).

Kundrat, R., \& Urban, T. (2007). Analýza variability mikrosatelitů u populací masných plemen skotu $\mathrm{v}$ České Republice. In: VII-th International Conference of PhD. and MSc. Students "Genetics and Animal Breeding”, May, 17-18, Brno, 22-29 (in Czech).

Lirón, J.P., Peral-García, P., \& Giovambattista, G. (2006). Genetic characterization of Argentine and Bolivian Creole cattle breeds assessed through microsatellites. Journal of Heredity, 97(4), 331-339. doi: 10.1093/jhered/es1003.

Loftus, R.T., Ertugrul, O., Harba, A.H., El-Barody, M.A.A., MacHugh, D.E., Park, S.D.E., \& Bradley, D.G. (1999). A microsatellite survey of cattle from a centre of origin: the Near East. Molecular Ecology, 8(12), 2015-2022. doi: 10.1046/j.1365294x.1999.00805.x.

Novoa, M.A., \& Usaquén, W. (2010). Population genetic analysis of the Brahman cattle (Bos indicus) in Colombia with microsatellite markers. Journal of Animal Breeding and Genetics, 127(2), 161-168. doi: 10.1111/j.1439-0388.2009.00811.x.

Peakall, R., \& Smouse, P.E. (2012). GenAIEx 6.5: genetic analysis in Excel. Population genetic software for teach- ing and researchd - an update. Bioinformatics, 28(19), 2537-2539. doi: 10.1093/bioinformatics/bts460.

Putnova, L., Vrtkova, I., Srubarova, P., \& Stehlik, L. (2011). Utilization of a 17 microsatellites set for bovine traceability in $\mathrm{Czech}$ cattle populations. Iranian Journal of Applied Animal Science, 1(1), 31-37. http://ijas.iaurasht.ac.ir/article_513439.html.

Sifuentes-Rincón, A.M., Puentes-Montiel, H., \& ParraBracamonte, G.M. (2007). Assessment of genetic structure in Mexican Charolais herds using microsatellite markers. Electronic Journal of Biotechnology, 10(4), 492-499. doi: 10.4067/S071734582007000400002.

Simčić, M., Čepon, M., Horvat, S., Jovanović, S., Gantner, V., Dovč, P., \& Kompan, D. (2008). Genetic characterization of autochthonous cattle breeds Cika and Busha, using microsatellites. Acta agriculturae Slovenica, 2, 71-77.

Stevanović, J., Stanimirović, Z., Dimitrijević, V., Stojić, V., Fratrić, N., \& Lazarević, M. (2009). Microsatellite DNA polymorphism and its usefulness for pedigree verification in Simmental cattle from Serbia. Acta Veterinaria, 59(5-6), 621-631. doi: 10.2298/AVB0906621S.

Teneva, A., Todorovska, E., Tyufekchiev, N., Stella, A., Boettcher, P., \& Dimitrova, I. (2007). Molecular characterization of bulgarian livestock genetic resources. II: Microsatelite variation within and among Bulgarian cattle breeds. Biotechnology in Animal Husbandry, 23(5-6-1), 227-242. doi: 10.2298/BAH0701227T.

Vdovychenko, Yu.V., Voronenko V.I., Nayd'onova V.O., Omel'chenko L.O. (2012). M'yasne skotarstvo v stepoviy zoni Ukrayiny. Nova Kakhovka, PYEL (in Ukrainian).

Weir, B. (1996). Genetic data analysis II: Methods for discrete population genetic data. Sinauer Associates, Inc. Publishers Sunderland, Massachusetts.

Yoon, D.H., Kong, H.S., Oh, J.D., Lee, J.H., Cho, B.W., Kim, J.D., Jeon, K.J., Jo, C.Y., Jeon, G.J., \& Lee, H.K. (2005). Establishment of an individual identification system based on microsatellite polymorphisms in Korean cattle (Hanwoo). Asian-Australasian Journal of Animal Sciences, 18(6), 762-766. doi: 10.5713/ajas.2005.762.

Zinovieva, N.A., Popov, A.N., Ernst, L.K., Marzanov, N.S., Bochkarev, V.V., Strekozov, N.I., \& Brem, G. (1998). Metodicheskie rekomendatsii po ispol'zovaniyu metoda polimeraznoy tsepnoy reaktsii v zhivotnovodstve. Dubrovitsy, VIZh (in Russian). 